\title{
Measurement of inhibin-A ( $\alpha \beta A$ dimer) during the oestrous cycle, after manipulation of ovarian activity and during pregnancy in ewes
}

\author{
P. G. Knight ${ }^{1}$, S. A. Feist ${ }^{1}$, D. S. Tannetta ${ }^{1}$, E. C. L. Bleach ${ }^{1}$, \\ P. A. Fowler ${ }^{2}, \mathrm{M} . \mathrm{O}^{\prime}$ Brien $^{3}$ and N. P. Groome ${ }^{3}$ \\ ${ }^{1}$ School of Animal and Microbial Sciences, The University of Reading, Whiteknights, Reading RG6 6AJ, \\ $U K ;{ }^{2}$ Department of Obstetrics and Gynaecology, University of Aberdeen, Foresterhill, Aberdeen AB25 2ZD, \\ $U K$; and ${ }^{3}$ School of Biological and Molecular Sciences, Oxford Brookes University, Oxford OX3 OBP, UK
}

A new two-site ELISA was validated for ovine plasma and used to measure circulating inhibin-A concentrations during a synchronized oestrous cycle in four ewes and throughout pregnancy in six ewes. Inhibin A concentrations were also determined in four ewes during chronic treatment with a GnRH agonist and after subsequent exposure to pregnant mares' serum gonadotrophin (PMSG) to stimulate ovarian follicular development. Concentrations of $\mathrm{FSH}, \mathrm{LH}$, oestradiol and progesterone were determined by radioimmunoassay. The detection limit of the inhibin-A ELISA was approximately $50 \mathrm{pg} \mathrm{ml}^{-1}$ and no significant crossreaction was observed with a range of related molecules including activin- $A$, inhibin- $B$, activin- $B$, follistatin and $\alpha_{2}$-macroglobulin. Inhibin- $A$ concentrations were below the detection limit in plasma from hypophysectomized and ovariectomized ewes. During the oestrous cycle, plasma inhibin-A concentrations (approximately $0.3-0.4 \mathrm{ng} \mathrm{ml}^{-1}$ ) did not vary during the follicular phase whereas plasma oestradiol increased approximately tenfold. After the preovulatory LH/FSH surge, inhibin-A fell to a nadir (approximately $0.15 \mathrm{ng}$ $\mathrm{ml}^{-1}$ ) coincident with the peak of the postovulatory FSH rise. During the next 2 days, FSH concentrations fell to basal values as inhibin-A concentrations increased $(P<0.05)$ to a peak (approximately $0.5 \mathrm{ng} \mathrm{ml}^{-1}$ ) 3 days after the preovulatory $\mathrm{LH} / \mathrm{FSH}$ surge. Over the following 3 days, FSH values increased again $(P<0.05)$ as inhibin-A concentrations fell to approximately $0.25 \mathrm{ng} \mathrm{ml}^{-1}(P<0.05)$. Chronic GnRH agonist treatment suppressed FSH concentrations by about $50 \%$, while inhibin-A and oestradiol concentrations fell below detection limits. Within 2 days after the PMSG injection, concentrations of inhibin- $A$ (approximately $4.5 \mathrm{ng} \mathrm{ml}^{-1}$ ) and oestradiol (approximately $20 \mathrm{pg} \mathrm{ml}^{-1}$ ) had increased to very high values, while FSH concentrations had been reduced by a further $50 \%$. Plasma concentrations of inhibin-A and FSH were similar to those in nonpregnant ewes during the first 60 days of gestation, but inhibin-A values fell markedly (sevenfold; $P<0.01$ ) between days 60 and 90 , coincident with a twofold decrease in FSH $(P<0.05)$. Inhibin A and FSH concentrations remained low for the remainder of gestation and were positively correlated throughout pregnancy $(r=0.48 ; P<0.005)$. These observations support an endocrine feedback role for ovarian inhibin-A and oestradiol in controlling the secondary (postovulatory) FSH surge in ewes, but indicate that an increase in oestradiol is responsible for the characteristic reduction in FSH during the early to mid-follicular phase. The reduced secretion of FSH from mid- to late pregnancy cannot be attributed to increased inhibin-A secretion by the feto-placental unit, but most likely reflects increased steroid secretion from this source.

\section{Introduction}

The relative importance of inhibins as gonadal feedback regulators of pituitary FSH secretion in sheep has been difficult to evaluate, mainly due to the unavailability of specific and

Received 24 July 1997 sensitive immunoassays applicable to peripheral serum or plasma from this species. Despite this lack of information on circulating inhibin concentrations in sheep, immunoneutralization studies (Mann et al., 1989, 1990; Wrathall et al., 1990; Campbell et al., 1995) and experiments involving the administration of exogenous inhibin (McNeilly, 1984; Findlay et al., 1987; Knight and Castillo, 1988; Martin et al., 1988) support an endocrine role for ovarian inhibin in modulating FSH secretion. 
Two isoforms of inhibin have been identified, referred to as inhibin $\mathrm{A}$ and inhibin $\mathrm{B}$. Both are disulfide-linked dimers that share a common $\alpha$ subunit, but have distinct $\beta$ subunits, termed $\beta A$ and $\beta B$, respectively (Ying, 1988; Baird and Smith, 1993). Although free $\alpha$ or $\beta$ subunits have no intrinsic inhibin-like biological activity in terms of pituitary FSH suppression, the gonads synthesize and secrete an excess of free $\alpha$ subunit (Knight, 1996), potentially confounding the interpretation of inhibin measurements made using 'first generation' inhibin radioimmunoassays (for example, McNeilly et al., 1989; Campbell et al., 1990; Findlay et al., 1990) that used antibodies directed against the $\alpha$ subunit and which were therefore unable to discriminate between the free $\alpha$ subunit, inhibin-A and inhibin-B. Recently, a new generation of highly sensitive and specific, two-site inhibin immunoassays has been developed, based on the use of monoclonal antibodies against defined epitopes on the human $\alpha, \beta A$ and $\beta B$ inhibin subunits. These assays have been used extensively to quantitate circulating inhibin-A and -B in humans (Groome et al., 1994, 1996; Muttukrishna ef al., 1994, 1995). However, they have proved to be unsuitable for plasma inhibin measurement in sheep and cattle owing to the poor crossreactivity of the $a$ subunit monoclonal antibody used (clone R1) with ovine or bovine inhibin-A (N. P. Groome and P. G. Knight, unpublished).

In an attempt to overcome this problem, a new monoclonal antibody was generated against a more conserved region of the mature $\alpha \mathrm{C}$ subunit. As anticipated, use of this antibody in a two-site ELISA format provided an inhibin-A assay of broader species specificity. The objective of the present study was to validate this assay for ovine plasma in order to allow the measurement of circulating concentrations of inhibin- $\mathrm{A}$ in ewes in various endocrinological states, including the normal oestrous cycle, after manipulation of ovarian function and during pregnancy, and to relate these to the profiles of other reproductive hormones.

\section{Materials and Methods}

\section{Animals and sample collection}

Inhibin-A during the oestrous cycle. During the mid-breeding season, four crossbred (Mule) ewes were treated with intravaginal progestagen sponges (Chronogest; Intervet UK Ltd, Cambridge) for 12 days to synchronize oestrus. Blood samples $(4 \mathrm{ml})$ were collected via indwelling jugular vein catheters every $12 \mathrm{~h}$ for 20 days starting 3 days before withdrawal of the progestagen sponges. Additional blood samples were collected every $2 \mathrm{~h}$ over 5 days, beginning $12 \mathrm{~h}$ before progestagen withdrawal, in order to define hormone profiles in the peri-ovulatory period more clearly.

Inhibin-A after manipulation of ovarian function with $G n R H$ agonist and PMSG. Four non-synchronized, crossbred ewes received a subcutaneous slow-release implant containing $3.6 \mathrm{mg}$ of the superactive GnRH agonist Zoladex (a gift from Zeneca, Macclesfield, Cheshire) to suppress gonadotrophin secretion and inhibit ovarian activity (Knight and Castillo, 1988). Three weeks later, a second implant was inserted, and after a further 3 weeks, all ewes received an i.m. injection of
2000 iu of pregnant mares' serum gonadotrophin (PMSG) (Folligon; Intervet, Boxmeer) to stimulate follicular development. Blood was collected from a jugular vein every $1-2$ weeks from the time of placing the first GnRH agonist implant and every $12 \mathrm{~h}$ for $48 \mathrm{~h}$ from the time of PMSG administration.

Inhibin-A during pregnancy. Blood samples were obtained by venepuncture from seven groups of pregnant Scottish Blackface ewes ( $n=5-6$ per group) before slaughter at 35,40 , $60,90,110,125$ and 135 days of gestation. The samples were collected initially as part of another study (Sinclair et al., 1996).

\section{Inhibin-A ELISA}

Preparation and biotinylation of inhibin a monoclonal antibody. A new monoclonal antibody (mAb) to the mature $\alpha \mathrm{C}$ inhibin subunit was made by immunizing Bacillus Calmette-Guerin (BCG)-primed hypogonadal mice with a synthetic peptide corresponding to residues $1-32$ of the human $\alpha \mathrm{C}$ subunit coupled to tuberculin-purified protein derivative as described by Groome and Lawrence (1991). The immunization schedule and splenocyte-myeloma fusion protocol followed were similar to those reported previously (Groome and Lawrence, 1991; Groome et al., 1996). Hybridoma fusion supernatants were screened using microplates coated with purified $32 \mathrm{kDa}$ bovine inhibin following a standard ELISA procedure (Groome et al., 1990; Groome and Lawrence, 1991). Positive clones were expanded and recloned in methyl cellulose and one clone (173 $29 \mathrm{H} 2$ ) identified as an $\mathrm{IgG}_{1}$-secretor was selected for use in the present assay since further screening revealed high affinity binding to both bovine $32 \mathrm{kDa}$ inhibin and human $32 \mathrm{kDa}$ inhibin. This clone was grown to produce ascites fluid in nude mice and the IgG was purified by standard protein $G$ chromatography and biotinylated as described by Groome et al. (1990).

Assay procedure. Serial dilutions of purified $32 \mathrm{kDa}$ bovine inhibin-A (assay standard; $1.56-100 \mathrm{pg}$ per $100 \mu \mathrm{l}$ ), pooled ovine follicular fluid (1:5000-1:40000 dilution) and ovine plasma samples (neat to $1: 8$ dilution) were prepared using hypophysectomized ewe plasma (kindly provided by H. Buttle, Institute of Grassland and Environmental Research, Hurley, Berks) as diluent to compensate for any matrix effect of ovine plasma in the assay. No endogenous inhibin-A immunoreactivity was detectable in this plasma pool or in plasma from an ovariectomized ewe. Aliquots $(100 \mu \mathrm{l})$ of diluted standards and test samples were mixed with an equal volume of ELISA buffer $(10 \%(\mathrm{w} / \mathrm{v})$ BSA, $5 \%(\mathrm{v} / \mathrm{v})$ Triton X-100, $0.15 \mathrm{~mol} \mathrm{NaCl} \mathrm{l}^{-1}$ in $0.1 \mathrm{~mol}$ Tris- $\mathrm{HCl}$ buffer $\left.I^{-1}, \mathrm{pH} 7.5\right)$ before adding $50 \mu \mathrm{l}$ distilled water containing $6 \%(\mathrm{v} / \mathrm{v})$ hydrogen peroxide (Sigma UK Ltd, Poole, Dorset) to oxidize methionine residues on inhibin and enhance reactivity with $\mathrm{E} 4$ $\mathrm{mAb}$ (Knight and Muttukrishna, 1994). Tubes were mixed and incubated for $30 \mathrm{~min}$ at room temperature before transferring duplicate $100 \mu \mathrm{l}$ aliquots to E4-coated microplates (Groome and O'Brien, 1993) which were placed in a humid box and incubated overnight on a microplate shaker (Wellmix, Denley Instruments, Billinghurst, West Sussex). Plates were washed (15 cycles) before adding $50 \mu \mathrm{l}$ ELISA buffer containing 
approximately $25 \mathrm{ng}$ biotinylated $\alpha$ subunit specific $\mathrm{mAb}(\mathrm{mAb}$ $17329 \mathrm{H} 2 ; 0.5 \mathrm{mg} \mathrm{ml}^{-1}$ ) to each well. After incubating for $1 \mathrm{~h}$ at room temperature on a microplate shaker, plates were washed (15 cycles) and $50 \mu \mathrm{l}$ ELISA diluent containing streptavidin-alkaline phosphatase conjugate (Dako, High Wycombe, Bucks; $1: 10^{5}$ dilution) was added to each well. After a further $\mathrm{I} \mathrm{h}$ incubation on a microplate shaker, plates were washed thoroughly (15 cycles) and bound alkaline phosphatase was quantitated using a commercially available ELISA amplification kit (Immuno Select ELISA Amplification System; GIBCO BRL, Uxbridge, Middlesex) used according to the supplier's instructions. Absorbance at $492 \mathrm{~nm}$ was read on a microplate reader (MR700; Dynatec Laboratories, Billinghurst, Sussex) and data processed by immunoassay curve-fitting software (Riacalc, Pharmacia, Milton Keynes, Bucks). Crossreactivities of related molecules were assessed and recovery experiments were performed.

\section{Gonadotrophin and steroid assays}

Gonadotrophins. Plasma concentrations of FSH were determined using a homologous ovine $\mathrm{FSH}$ radioimmunoassay kit provided by NIDDK (Bethesda, MD) as reported previously (Knight and Castillo, 1988; Wrathall et al., 1990). The detection limit of the assay, expressed as the amount of FSH standard (NIDDK-oFSH-RPI) required to inhibit the binding of the iodinated tracer (NIDDK-oFSH-II) to the antibody (NIDKKanti-oFSH-1; final dilution 1:16 000) by $20 \%$ was $0.025 \mathrm{ng}$ per tube. Mean intra- and interassay coefficients of variation (CV) were $4 \%$ and $7 \%$, respectively. Plasma concentrations of LH were determined as described previously (Knight and Castillo, 1988) using NIH-LH-S16 as standard. The limit of detection was $0.1 \mathrm{ng}$ per tube and mean intra- and interassay CVs were 8 and $11 \%$, respectively.

Steroids. Concentrations of oestradiol in plasma samples were determined using a commercial human oestradiol radioimmunoassay kit (Biostat, Stockport) modified and validated for ovine plasma as described by Tannetta et al. (1997). Intra-assay and interassay $\mathrm{CVs}$ were $12 \%$ and $21 \%$, respectively, and the detection limit of the assay was $0.25 \mathrm{pg}$ per tube (equivalent to $0.5 \mathrm{pg} \mathrm{ml}^{-1}$ ovine plasma). Concentrations of progesterone in plasma were measured by direct ELISA as described previously (Sauer et al., 1986; Wrathall et al., 1990). The detection limit was $0.17 \mathrm{ng} \mathrm{ml}^{-1}$ and intra- and inter-plate CVs were $<10 \%$.

\section{Statistical analysis}

Repeated-measures analysis of variance (ANOVA) and posthoc Fisher's PLSD test for individual pairwise comparisons were used to determine whether plasma hormone concentrations varied significantly during the oestrous cycle. The same tests were used to analyse the changes in plasma hormones after GnRH-agonist treatment and subsequent PMSG injection. Pregnancy data were evaluated by factorial ANOVA and post-hoc PLSD tests. In each study, simple regression analysis was also used to investigate relationships between concentrations of different hormones.

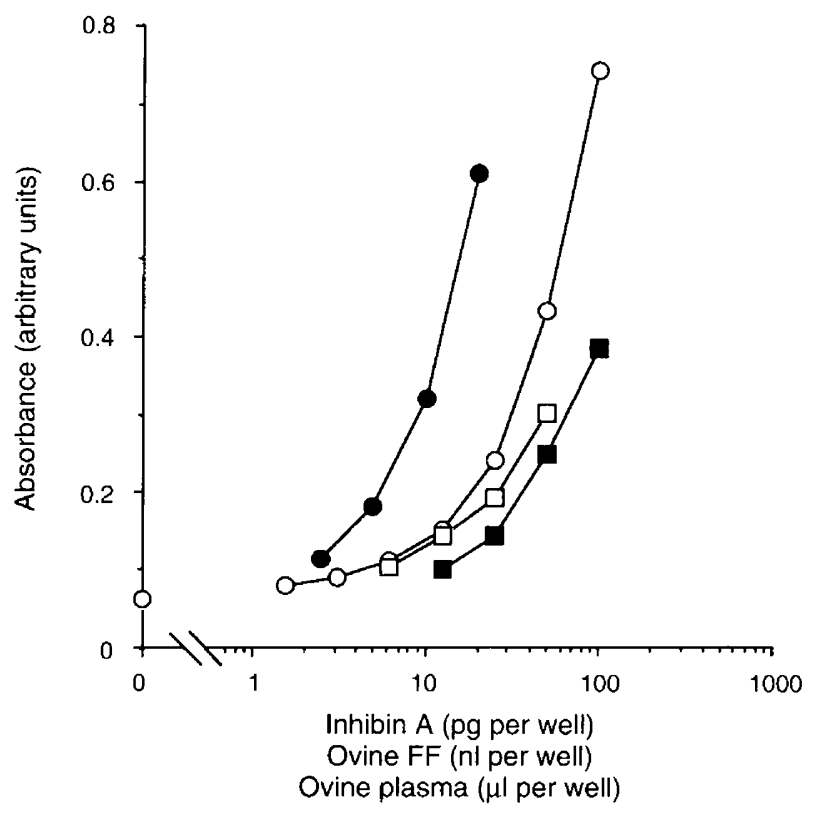

Fig. 1. Representative dose-response curves for the $32 \mathrm{kDa}$ bovine inhibin-A standard $(O)$, ovine follicular fluid $(\mathrm{FF})(\mathbf{O})$ and two ovine plasma pools $(\square, \mathbf{\square})$ in the inhibin-A ELISA. Values are means of duplicate determinations.

\section{Results}

\section{Validation of the inhibin-A ELISA for sheep plasma}

Serial dilutions of pooled ovine follicular fluid and ovine serum gave ELISA response curves parallel to the purified $32 \mathrm{kDa}$ bovine inhibin standard (Fig. 1). Neither recombinant human (rh) activin- $A$, rh activin- $B$, rh inhibin- $B$ (gifts from Genentech Inc., South San Francisco, CA) at $25 \mathrm{ng} \mathrm{ml}^{-1}$, bovine inhibin $\alpha$ subunit (pro- $\alpha \mathrm{C}$; Knight et al., 1989) at $100 \mathrm{ng}$ $\mathrm{ml}^{-1}$, rh follistatin-288 (a gift from NIDDK, Baltimore, MD) at $100 \mathrm{ng} \mathrm{ml}^{-1}$ nor $\alpha_{2}$-macroglobulin (Calbiochem, Nottingham) at $500 \mu \mathrm{g} \mathrm{ml}^{-1}$ showed any significant crossreaction in the ELISA (all $<0.1 \%$ relative to the bovine inhibin-A standard). Recovery of bovine inhibin standard ( $50 \mathrm{pg}$ per $100 \mu \mathrm{l})$ added to individual ovine plasma samples before assay was $91 \pm 8 \%$ $(n=8)$. The detection limit was approximately $50 \mathrm{pg} \mathrm{ml}$ ovine plasma and within- and between-plate CVs were $<10 \%$.

\section{Inhibin-A during the oestrous cycle}

Mean serum profiles of inhibin-A, FSH, LH and progesterone based on samples taken every $12 \mathrm{~h}$ throughout a synchronized oestrous cycle of four ewes are shown (Fig. 2a-c). The corresponding hormone profiles (inhibin-A, LH, FSH, oestradiol) determined from the samples taken every $2 \mathrm{~h}$ for 5 days over the periovulatory period are also shown (Fig. $2 \mathrm{~d}-\mathrm{e}$ ). Plasma oestradiol was only assayed in every third sample (that is, at intervals of $6 \mathrm{~h}$ ) during this period of more frequent sampling. Plasma concentrations of FSH, LH, oestradiol and progesterone showed the expected pattern of change during the cycle with a preovulatory surge in $\mathrm{LH}$ and FSH occurring $50 \mathrm{~h}$ after withdrawal of the progestogen insert. In contrast to 
(a)

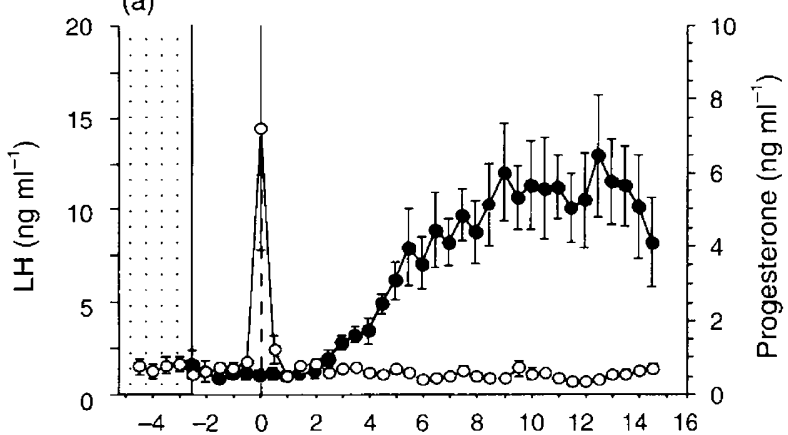

(b)

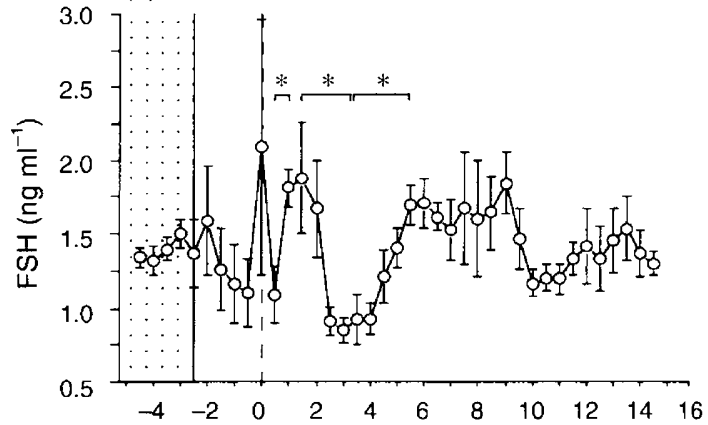

(c)

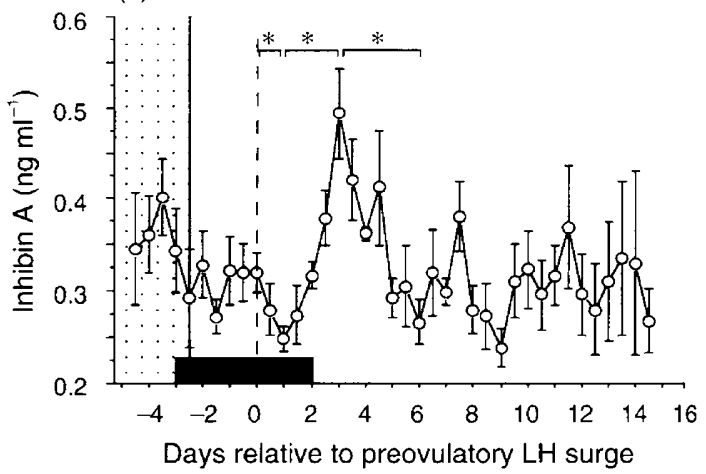

(d)

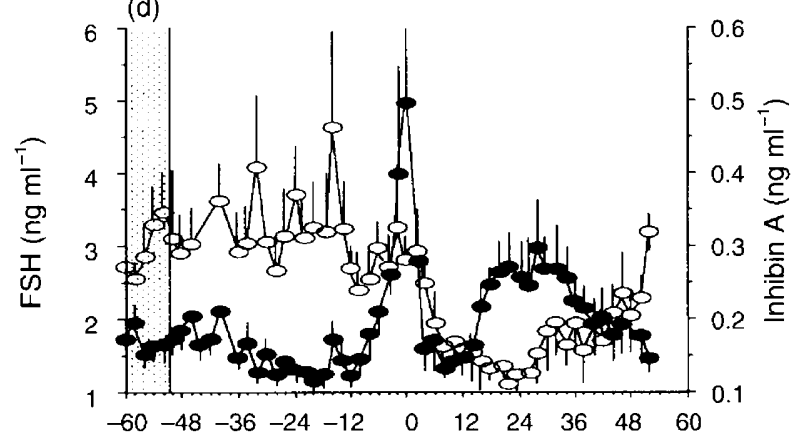

(e)

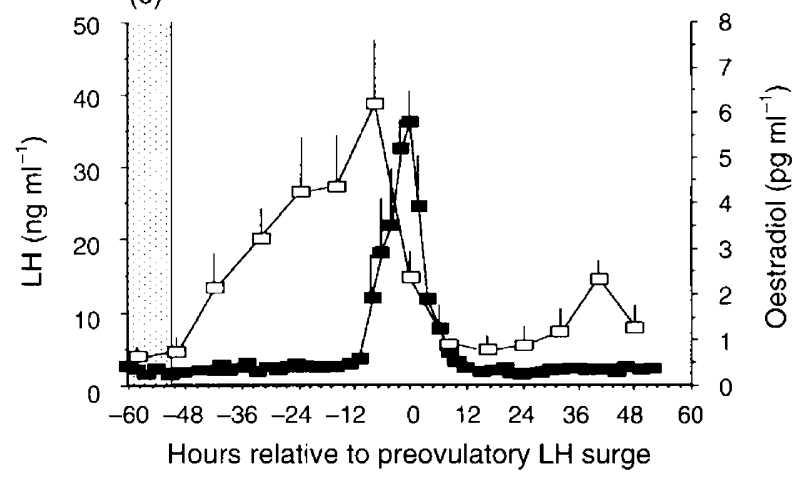

Fig. 2. Mean ( \pm SEM) concentrations of (a) LH $(O)$ and progesterone $(\bullet)$, (b) FSH, (c) inhibin-A, (d) FSH $(\bullet)$ and inhibin-A $(O)$ and (e) LH ( $\mathbf{a}$ ) and oestradiol $(\square)$ in peripheral plasma of four ewes during a progestagen ( $\square$ )-synchronized oestrous cycle. (a-c) show data based on blood samples taken twice a day for 20 days; while (d-e) show data based on the more frequent sampling (every 2 h) during the periovulatory period (corresponding to the black bar in (c)). Note that oestradiol measurements were restricted to the periovulatory period. ( $\square$ ) denotes the presence of an intravaginal progestagen-containing sponge and the vertical dashed line in $(\mathrm{a}-\mathrm{c})$ indicates the peak of the preovulatory $\mathrm{LH}$ surge. ${ }^{*} \mathrm{P}<0.05$.

plasma oestradiol, inhibin-A showed no consistent pattern of change in response to progestagen withdrawal and did not increase significantly during the follicular phase (Fig. 2d,e). However, from the time of the preovulatory LH/FSH surge, inhibin-A concentrations fell steadily (approximately $50 \%$; $P<0.01$ ) to reach a nadir $22 \mathrm{~h}$ later coincident with the peak of the secondary FSH surge (Fig. 2d). During the next $36 \mathrm{~h}$, inhibin-A increased progressively (approximately twofold; $P<0.01$ ) and this was accompanied by a progressive $70 \%$ reduction in plasma FSH $(P<0.01)$. Over the next 3 days, FSH increased again by about $100 \%(P<0.01)$ (Fig. 2b) concomitant with an approximate fall of $90 \%(P<0.05)$ in inhibin-A (Fig. 2c). When all plasma samples collected from the four ewes across the cycle are considered, inhibin-A showed a weak inverse correlation with FSH $(r=-0.21 ; P<0.001 ; n=416)$, but not with LH $(r=-0.05 ; P=0.36 ; n=416)$.

\section{Inhibin-A after manipulation of ovarian function with $\mathrm{GnRH}$} agonist and $P M S G$

Chronic exposure of ewes to the GnRH agonist was associated with a reduction in plasma concentrations of $\mathrm{FSH}$, inhibin-A and oestradiol, the last two falling to undetectable values (Fig. 3). Administration of PMSG to reinstate follicle development promoted a marked increase in plasma inhibin- $A$ $(P<0.001)$ and oestradiol $(P<0.001)$, while FSH concentrations were reduced further $(P<0.01)$. Concentrations of

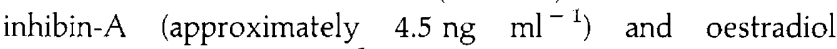
(approximately $21 \mathrm{pg} \mathrm{ml}^{-1}$ ) observed $48 \mathrm{~h}$ after PMSG administration were about 15 -fold and 3.5 -fold higher than corresponding values reached in the normal preovulatory period. Plasma inhibin-A and oestradiol were positively correlated $(r=0.95 ; P<0.0001)$. Plasma FSH was negatively correlated 


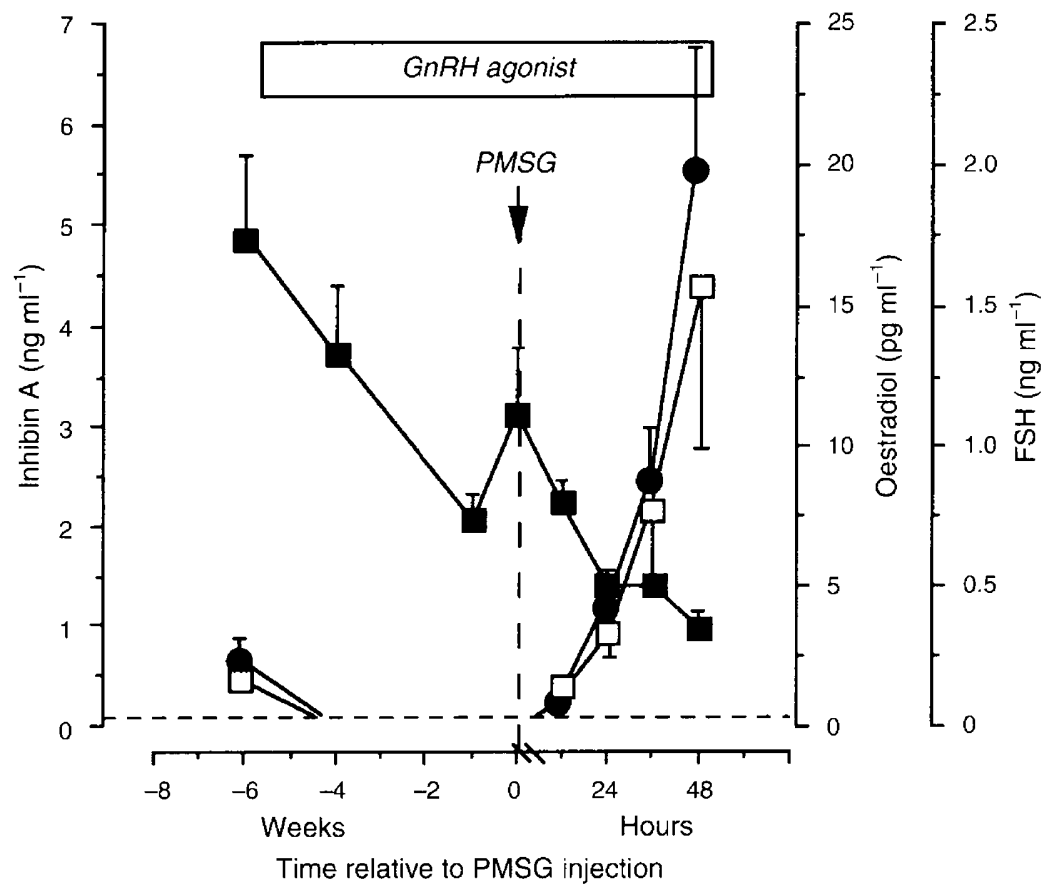

Fig. 3. Changes in mean ( \pm SEM) concentrations of inhibin-A ( $\square$ ), oestradiol $(-$ ) and FSH (ם) in peripheral plasma of four ewes in response to chronic GnRH-agonist treatment ( $\square$ ) and subsequent injection of a superovulatory dose of pregnant mares' serum gonadotrophin (PMSG) (2000 iu).

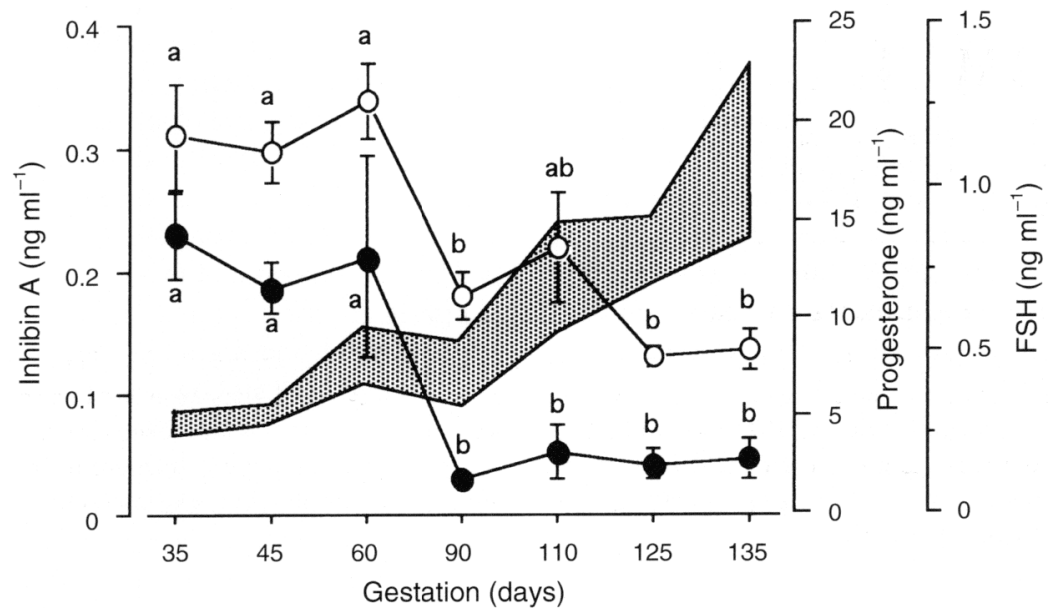

Fig. 4. Mean ( \pm SEM) concentrations of inhibin-A $(-$ ) FSH $(O)$ and progesterone $(\square)$ in peripheral plasma of ewes (five to six ewes per time-point) sampled between days 35 and 135 of gestation. Means without a common letter are significantly $(P<0.05)$ different.

with both inhibin-A $(r=-0.47 ; P<0.01)$ and oestradiol $(r=-0.55, P<0.01)$.

\section{Inhibin-A during pregnancy}

Between days 35-60 of gestation, plasma concentrations of inhibin-A, FSH and progesterone were similar to those observed in nonpregnant ewes during the luteal phase (Fig. 4).
Plasma progesterone increased steadily from about $5 \mathrm{ng} \mathrm{ml}^{-1}$ on day 35 to about $18 \mathrm{ng} \mathrm{ml}^{-1}$ on day 135 of gestation. Between days 60 and 90 of gestation, plasma inhibin-A fell about sevenfold $(P<0.01)$ while FSH fell about twofold $(P<0.05)$. Both hormones remained at basal values for the rest of gestation. Plasma progesterone was negatively correlated with inhibin-A $(r=-0.53, P<0.001)$ and FSH $(r=-0.51$, $P<0.001)$ during pregnancy, while inhibin-A and FSH were positively correlated $(r=0.48 ; P<0.01)$. 


\section{Discussion}

It has been possible, by incorporating a new biotinylated 'detector antibody' (clone $17329 \mathrm{H2}$; anti- $\alpha \mathrm{C}^{1-32}$ ) into an established amplified two-site ELISA for human inhibin-A (Groome et al., 1994; Muttukrishna et al., 1994), to generate an assay with improved crossreactivity with bovine/ovine inhibin-A. As reported here, the assay is satisfactory in terms of its reproducibility, accuracy and specificity and, although sensitivity is not as high as that of the original inhibin-A ELISA, it can measure inhibin-A concentrations in peripheral blood of female sheep in a variety of physiological states. Plasma concentrations of inhibin- $A$ in cyclic heifers are considerably lower than in sheep and therefore, in its present form, the assay is not sufficiently sensitive for use in cattle.

$m R N A s$ for both $\beta A$ and $\beta B$ subunits are expressed in ovine granulosa cells (Engelhardt et al., 1993). It is therefore likely that inhibin- $B$ is also synthesized and secreted by the sheep ovary, perhaps in a differential manner to inhibin- $A$, as indicated by recent studies in humans (Groome et al., 1996) and rats (Woodruff et al., 1996). However, when assayed using the same inhibin-B ELISA (Groome et al., 1996) inhibin-B concentrations in pooled ovine follicular fluid $\left(105 \pm 16 \mathrm{ng} \mathrm{ml}^{-1}\right.$, $n=3$ pools) were some 50-100 times lower than inhibin-A concentrations (S. A. Feist and P. G. Knight, unpublished observations). Moreover, inhibin-B concentrations in plasma pools from cyclic, ovariectomized, PMSG-treated and pregnant ewes were found to be below the assay detection limit $\left(<20 \mathrm{pg} \mathrm{ml}^{-1}\right.$, expressed in terms of hr inhibin-B standard). Since inhibin-B has never been isolated from sheep follicular fluid and is thus unavailable for testing, the possibility that poor crossreaction of sheep inhibin- $B$ in the human inhibin- $B$ ELISA accounts for the very low values in sheep follicular fluid and plasma cannot be excluded. Despite this uncertainty, the present balance of evidence suggests that inhibin- $A$ is the major isoform synthesized and secreted by the sheep ovary. So far, our attempts to introduce the new broad specificity anti- $\alpha \mathrm{C}$ monoclonal into the existing inhibin-B ELISA (Groome et al., 1996) have not been successful.

Contrary to expectations based on findings during the human menstrual cycle (Groome et al., 1994; Muttukrishna et al., 1994) and the rat oestrous cycle (Fahy et al., 1995; Woodruff et al., 1996), plasma inhibin-A concentrations, as measured by specific ELISA, did not increase during the follicular phase in ewes, despite the occurrence of an approximate tenfold increase in plasma oestradiol derived from growing preovulatory follicle(s). As suggested previously (Tsonis et al., 1988; McNeilly et al., 1989), this result indicates that the characteristic fall in FSH during the early follicular phase is due mainly to an increased negative feedback action of follicular oestradiol, rather than an increase in inhibin feedback. It also reinforces earlier evidence that follicles, other than large oestrogen-active ones, produce appreciable amounts of inhibin and contribute significantly to concentrations present in the peripheral circulation (Tsonis et al., 1983; Mann et al., 1992; Engelhardt et al., 1993). Immediately after the preovulatory LH/FSH surge, plasma inhibin-A values fell steeply to reach a nadir coincident with the peak of the postovulatory FSH surge. Findlay et al. (1990) also observed a fall in plasma ir-inhibin at this time while, in contrast, others (McNeilly et al., 1989;
Campbell et al., 1990) reported an increase after the preovulatory LH surge. The present observation suggests that, as in rats (Hasegawa et al., 1989; Fahy et al., 1995), the postovulatory FSH surge in ewes is generated, at least in part, by a reduction in inhibin feedback. However, an abrupt reduction in plasma oestradiol began $2-6 \mathrm{~h}$ before the preovulatory LH/FSH peak and preceded the fall in inhibin-A by $6-8 \mathrm{~h}$. Given that both inhibin- $\mathrm{A}$ and oestradiol fell to basal values after the preovulatory LH/FSH surge and that the ovine pituitary is highly sensitive to the negative feedback effects of inhibin and oestradiol (Martin et al., 1988; Muttukrishna and Knight, 1990), it is likely that a reduction in concentrations of both hormones contributes to the generation of the postovulatory FSH rise required to initiate the FSH-dependent growth of a new cohort of follicles (Ginther et al., 1995).

Previous studies of circulating concentrations of ir-inhibin in ewes using a subunit-directed radioimmunoassays have generated conflicting results with regard to the pattern of secretion during the oestrous cycle (McNeilly et al., 1989; Campbell et al., 1990; Findlay et al., 1990). None of these is wholly consistent with the present findings obtained using a specific inhibin-A assay. It is likely that these discrepancies can be accounted for mainly by the inherent limitations of the "first generation' radioimmunoassays used in earlier studies, although other differences between studies (for example, breed, experimental design, sampling method) could also contribute to the variable findings. In addition, differences between ewes, in the follicle population present at the time of luteal regression, would be expected to generate additional variation in inhibin and oestradiol secretory profiles. In the absence of information on ovarian follicular dynamics in the ewes used in the present study, the observed changes in peripheral hormone concentrations cannot be directly associated to the growth of discrete follicle waves as recently identified in sheep (Ginther et al., 1995; Souza et al., 1996).

Chronic exposure of ewes to a superactive GnRH agonist to suppress gonadotrophin secretion and arrest follicular development (Knight and Castillo, 1988; Picton et al., 1990) reduced plasma inhibin-A and oestradiol to undetectable concentrations (as observed in ovariectomized or hypophysectomized ewes), supporting the view that ovarian follicles are the principal source of inhibin- $A$ in the peripheral circulation. This finding is consistent with those of Findlay et al. (1990) who observed a reduction in ir-inhibin and oestradiol in ovarian vein plasma of ewes after cauterization of visible follicles on the ipsilateral ovary. As anticipated, restoration of follicle growth, by administration of a superovulatory dose of PMSG, in the ewes treated with the GnRH-agonist promoted a rapid and parallel increase in plasma inhibin-A and oestradiol. Increases in ir-inhibin secretion in ewes after exogenous FSH treatment have been reported previously (McNeilly et al., 1989; McNatty et al., 1993); however, the present data confirm that a substantial increase in follicular production of the $\alpha-\beta A$ dimer occurs.

The changes observed in plasma inhibin- $A$ in the pregnant ewes in the present study support previous findings obtained using the 'Monash' inhibin radioimmunoassay (Findlay et al., 1991). Inhibin-A concentrations were similar to those in nonpregnant animals until day 60 of gestation, after which they fell about sevenfold, to remain at basal values until at least day 135 of gestation (last time-point studied). This finding contrasts 
with human pregnancy (Muttukrishna et al., 1995), during which circulating inhibin-A concentrations are greatly increased, particularly during the third trimester when the feto-placental unit is the predominant source of inhibin-A reaching the maternal circulation (Petraglia et al., 1994). Our observation' that plasma FSH also fell significantly between days $60-90$, and was positively correlated with inhibin-A, confirms that any reciprocal relationship between inhibin and FSH is lost during pregnancy in ewes (Jenkin et al., 1995). This loss is presumably a result of the combined negative feedback action of oestrogens and progesterone (Phillips et al., 1988) that are secreted in increasing amounts by the developing fetoplacental unit (Challis, 1971; Findlay et al., 1991; Jenkin et al., 1995).

In conclusion, the development and validation of a new inhibin-A ELISA with broader species specificity than the original assay (Groome et al., 1994) has enabled us to clarify the relationship between circulating inhibin- $A$ and other reproductive hormones during the ovine oestrous cycle, pregnancy, and after ovarian manipulation. This assay should prove useful for further endocrinological studies in sheep, although the challenge remains to develop a comparable assay capable of detecting inhibin-B in this species.

The authors thank K. Sinclair and C. Maltin for taking the blood samples from the pregnant sheep available and M. D. Fray and R. G. Glencross for their helpful contributions. They are grateful to P. Smith (NIDDK, Baltimore, MD) for the ovine gonadotrophin radioimmunoassay reagents and recombinant human follistatin and to J. P. Mather (Genentech, South San Francisco, CA) for the recombinant human inhibins and activins used to evaluate assay cross-reactivities. This work was supported by BBSRC and MAFF.

\section{References}

Baird DT and Smith KB (1993) Inhibin and related peptides in the regulation of reproduction Oxford Reviews of Reproductive Biology 15 191-232

Campbell BK, Mann GE, McNeilly AS and Baird DT (1990) The pattern of ovarian inhibin, estradiol and androstenedione secretion during the estrous cycle of the ewe Endocrinology 127 227-235

Campbell BK, Gordon BM, Tsonis CG and Scaramuzzi RJ (1995) The effect of acute immuno-neutralization of inhibin in ewes during the early luteal phase of the oestrous cycle on ovarian hormone secretion and follicular development Journal of Endocrinology 145 479-490

Challis JRG (1971) Sharp increase in free circulating oestrogens immediately before parturition in sheep Nature 229208

Engelhardt H, Smith KB, McNeilly AS and Baird DT (1993) Expression of messenger ribonucleic acid for inhibin subunits and ovarian secretion of inhibin and estradiol at various stages of the sheep estrous cycle Biology of Reproduction 49 281-294

Fahy PA, Wilson CA, Groome NP and Knight PG (1995) Changes in inhibin-A $\left(\alpha-\beta_{A}\right.$ dimer) and total $\alpha$ inhibin in the peripheral circulation and ovaries of rats after gonadotrophin-induced follicular development and during the nomal oestrous cycle Journal of Endocrinology 147 271-283

Findlay JK, Robertson DM and Clarke IJ (1987) Influence of dose and route of administration of bovine follicular fluid and the suppressive effect of purified bovine inhibin $\left(M_{\mathrm{r}} 31000\right)$ on plasma FSH concentrations in ovariectomized ewes Journal of Reproduction and Fertility 80 455-461

Findlay JK, Clarke IJ and Robertson DM (1990) Inhibin concentrations in ovarian and jugular venous plasma and the relationship of inhibin with FSH and LH during the ovine estrous cycle Endocrinology 126 528-535

Findlay JK, Doughton BW and Russel DC (1991) Peripheral concentrations of immunoreactive inhibin during pregnancy and parturition in the ewe Reproduction, Fertility and Development 3 543-549
Ginther OJ, Kot K and Wiltbank MC (1995) Association between emergence of follicular waves and fluctuations in FSH concentrations during the estrous cycle in ewes Theriogenology $\mathbf{4 3}$ 689-703

Groome N and Lawrence M (1991) Preparation of monoclonal antibodies to the $\beta_{A}$ subunit of ovarian inhibin using a synthetic peptide immunogen Hybridoma 10 309-316

Groome N and O'Brien M (1993) Immunoassays for inhibin and its subunits: further applications of the synthetic peptide approach Journal of Immunological Methods 165 167-176

Groome N, Hancock J, Betteridge A, Lawrence M and Craven R (1990) Monoclonal and polyclonal antibodies reactive with the $1-32$ amino terminal sequence of the alpha subunit of human $32 \mathrm{~K}$ inhibin Hybridoma 9 $31-41$

Groome NP, Illingworth PJ, O'Brien M, Cooke I, Ganesan TS, Baird DT and McNeilly AS (1994) Detection of dimeric inhibin throughout the human menstrual cycle by two-site enzyme immunoassay Clinical Endocrinology 6 717-723

Groome N, Illingworth P, O'Brien M, Pai R, Rodger FE, Mather J and McNeilly A (1996) Measurement of dimeric inhibin- $B$ throughout the human menstrual cycle Journal of Clinical Endocrinology and Metabolism 81 1400-1405

Hasegawa Y, Miyamoto K and Igarashi M (1989) Changes in serum concentrations of immunoreactive inhibin during the oestrous cycle of the rat Journal of Endocrinology 121 91-100

Jenkin G, McFarlane J and de Kretser DM (1995) Inhibin and activin in embryonic and fetal development in ruminants Journal of Reproduction and Fertility Supplement 49 177-186

Knight PG (1996) Roles of inhibins, activins and follistatin in the female reproductive system Frontiers in Neuroendocrinology 17 476-509

Knight PG and Castillo RJ (1988) Effects of bovine follicular fluid on gonadotrophin secretion in intact and chronically ovariectomized ewes before and after desensitization of pituitary gonadotrophs to gonadotrophin-releasing hormone Journal of Endocrinology 117 431-439

Knight PG and Muttukrishna S (1994) Measurement of dimeric inhibin using a modified two-site immunoradiometric assay specific for oxidized (Met $O$ ) inhibin Journal of Endocrinology 141 417-425

Knight PG, Beard AJ, Wrathall JHM and Castillo RJ (1989) Evidence that the bovine ovary secretes large amounts of inhibin $\alpha$-subunit and its isolation from bovine follicular fluid Joumal of Molecular Endocrinology 2 189-200

McNatty KP, Hudson NL, Heath DA, Shaw L, Bray L, Berry L and Lun S (1993) Effect of chronic FSH administration on ovarian follicular development, ovulation rate and corpora lutea formation in sheep Journal of Endocrinology 138 315-325

McNeilly AS (1984) Changes in FSH and the pulsatile secretion of LH during the delay in oestrus induced by treatment of ewes with bovine follicular fluid Journal of Reproduction and Fertility $\mathbf{7 2}$ 165-172

McNeilly AS, Swanston IA, Crow W, Tsonis CG and Baird DT (1989) Changes in the plasma concentrations of inhibin throughout the normal sheep oestrous cycle and after the infusion of FSH Journal of Endocrinology 120 295-305

Mann GE, Campbell BK, McNeilly AS and Baird DT (1989) Passively immunizing ewes against inhibin during the luteal phase of the oestrous cycle raises the plasma concentration of FSH Journal of Endocrinology 123 383-391

Mann GE, Campbell BK, McNeilly AS and Baird DT (1990) Effects of passively immunizing ewes against inhibin and oestradiol during the follicular phase of the oestrous cycle Journal of Endocrinology 125 417-424

Mann GE, McNeilly AS and Baird DT (1992) Hormone production in vivo and in vitro from follicles at different stages of the oestrous cycle in the sheep Journal of Endocrinology 132 225-234

Martin GB, Price CA, Thiery J-C and Webb R (1988) Interactions between inhibin, oestradiol and progesterone in the control of gonadotrophin secretion in the ewe Journal of Reproduction and Fertility 82 319-328

Muttukrishna S and Knight PG (1990) Effects of crude and highly purified bovine inhibin ( $M_{\mathrm{r}} 32000$ form) on gonadotrophin production by ovine pituitary cells in vitro: inhibin enhances gonadotrophin-releasing hormone-induced release of LH Joumal of Endocrinology 127 149-159

Muttukrishna S, Fowler PA, Groome NP, Mitchell GG, Robertson WR and Knight PG (1994) Serum concentrations of dimeric inhibin during the spontaneous human menstrual cycle and after treatment with exogenous gonadotrophin Human Reproduction 9 1634-1642

Muttukrishna S, George L, Fowler PA, Groome NP and Knight PG (1995) Measurement of serum concentrations of inhibin- $A$ ( $\alpha-\beta_{A}$ dimer) during human pregnancy Clinical Endocrinology 42 391-397 
Petraglia F, Gallinelli A, Aguzzoli L, Angiono S, Grande A, Bonati M and Genazzani AR (1994) Inhibin, activin and follistatin in human placenta. In Frontiers in Endocrinology Vol. 3: Inhibin and Inhibin-Related Proteins pp 199-208 Eds $\mathrm{H}$ Burger, J Findlay, D Robertson, D de Kretser and F Petraglia. Ares-Serono Symposia, Rome

Phillips CL, Lin L-W, Wu J, Guzman K, Milsted A and Miller WL (1988) $17 \beta$-estradiol and progesterone inhibit transcription of the genes encoding the subunits of ovine follicle-stimulating hormone Molecular Endocrinology 2 641-649

Picton HM, Tsonis CG and McNeilly AS (1990) FSH causes a time-dependent stimulation of preovulatory follicle growth in the absence of pulsatile LH secretion in ewes chronically treated with gonadotrophin-releasing hormone Journal of Endocrinoiogy 126 297-307

Sauer MJ, Foulkes JA, Worsfold A and Morris BA (1986) Use of progesterone 11-glucuronide-alkaline phosphatase conjugate in a sensitive microtitre-plate enzyme immunoassay of progesterone in milk and its application to pregnancy testing in dairy cattle Journal of Reproduction and Fertility 76 $375-391$

Sinclair KD, Tregaskes LD, MaxÆeld EK, Robinson JJ, Broadbent PJ and Maltin CA (1996) Fetal growth following temporary exposure of day 3 ovine embryos to an advanced uterine environment Theriogenology 45223

Souza CJH, Campbell BK and Baird DT (1996) Follicular dynamics and ovarian steroid secretion in sheep during anoestrous Journal of Reproduction and Fertility 108 101-106
Tannetta DS, Fray MD, Wrathall JHM, Bleach ECL, Glencross RG and Knight PG (1997) Effects of supplementary treatment with bovine growth hormone on hormonal and ovulatory responses to inhibin immunization in the ewe Journal of Reproduction and Fertility $110255-262$

Tsonis CG, Quigg H, Lee VWK, Leversha L, Trounson AO and Findlay JK (1983) Inhibin in individual ovine follicles in relation to diameter and atresia journal of Reproduction and Fertility $6783-90$

Tsonis CG, McNeilly AS and Baird DT (1988) Inhibin secretion by: the sheep ovary during the luteal and follicular phases of the oestrous cycle and following stimulation with FSH Journal of Endocrinology $117283-$ 291

Woodruff TK, Besecke LM, Groome NP, Draper LB, Schwartz NB and Weis J (1996) Inhibin A and inhibin B are inversely correlated to folliclestimulating hormone, yet are discordant during the follicular phase of the rat estrous cycle, and inhibin $A$ is expressed in a sexually dimorphic manner Endocrinology $1375463-5467$

Wrathall JHW, McLeod BJ, Glencross RG, Beard AJ and Knight PG (1990) Inhibin immunoneutralization by antibodies raised against synthetic peptide sequences of inhibin $\alpha$ subunit: effects on gonadotrophin concentrations and ovulation rate in sheep Journal of Endocrinology 124 167-176

Ying S-Y (1988) Inhibins, activins and follistatins: gonadal proteins modulating the secretion of follicle-stimulating hormone Endocrine Reviews 9 267-293 